\title{
Kinetics Studies of the Reaction of Co(bpb) with the Azide Ion in Binary Methanol-Water Mixtures
}

\author{
HASHEMI Javad ${ }^{1} \quad$ ALIZADEH Naader ${ }^{1, *} \quad$ MEGHDADI Soraia ${ }^{2} \quad$ AMIRNASR Mehdi $^{2}$ \\ ('Department of Chemistry, Faculty of Science, Tarbiat Modares University, P.O. Box 14115-175, Tehran, Iran; \\ ${ }^{2}$ Department of Chemistry, Isfahan University of Technology, P.O. Box 84156-83111, Isfahan, Iran)
}

\begin{abstract}
Co}(\mathrm{bpb})\left[\mathrm{bpbH} \mathrm{H}_{2}\right.$ is $N, N^{\prime}$-o-phenylenebis(pyridine-2-carboxamide), $\left.\mathrm{C}_{18} \mathrm{H}_{12} \mathrm{~N}_{4} \mathrm{O}_{2}\right]$ complex has active axial sites like a porphyrin complex. We studied the coordination of azide ion $\left(\mathrm{N}_{3}^{-}\right)$to $\mathrm{Co}(\mathrm{bpb})$ in binary methanol-water mixtures by spectrophotometric method at the temperature range of 283-303 K. From the temperature dependence of the rate constant, activation parameters $\left(E_{\mathrm{a}}, \Delta H^{\#}, \Delta S^{\#}\right.$, and $\left.\Delta G^{\#}\right)$ were obtained. An isokinetic temperature at about $302 \mathrm{~K}$ was observed at which the formation rate of $\mathrm{Co}(\mathrm{bpb})-\mathrm{N}_{3}^{-}$was more or less independent of the solvent composition. The resulting $\Delta H$ against $T \Delta S$ plot showed a good linear correlation, indicating the existence of enthalpy-entropy compensation in azide complexation process. Under optimum conditions and based on the absorbance of $\mathrm{Co}(\mathrm{bpb})-\mathrm{N}_{3}^{-}$ produced through complex formation, a spectrophotometric method for the determination of $\mathrm{N}_{3}^{-}$in solution was developed. A linear relationship between the absorbance and $\mathrm{N}_{3}^{-}$concentration was obtained in the range of $(0.85-5.00) \times$ $10^{-4} \mathrm{~mol} \cdot \mathrm{L}^{-1}\left(3.6-21.0 \mu \mathrm{g} \cdot \mathrm{mL}^{-1}\right)$. The detection limit was $2.5 \times 10^{-5} \mathrm{~mol} \cdot \mathrm{L}^{-1}\left(1.0 \mu \mathrm{g} \cdot \mathrm{mL}^{-1}\right)$. The proposed method was applied to the determination of $\mathrm{N}_{3}^{-}$anion in real water samples.
\end{abstract}

Key Words: Spectrophotometric; Kinetics; Binary mixture; Azide determination; Water sample

Similar to metalloporphyrins, $\mathrm{Co}(\mathrm{bpb})\left[\mathrm{bpbH} \mathrm{pb}_{2}\right.$ is $N, N^{\prime}$-o-phenylenebis (pyridine-2-carboxamide), $\left.\mathrm{C}_{18} \mathrm{H}_{12} \mathrm{~N}_{4} \mathrm{O}_{2}\right]$ (Scheme 1) ${ }^{[1]}$ complex has active axial sites and has a tendency towards complex formation with different anions such as halides and pseudohalides including azide $\left(\mathrm{N}_{3}^{-}\right)^{[12]}$. Azide complexes of several metallic cations have been systematically studied in several research laboratories, for understanding their coordination chemistry ${ }^{[3-5]}$ and developing analytical applications $\mathbf{s}^{[-1-15]}$. Sodium azide is a useful starting material for the preparation of heavy metal azides, pure sodium metal, hydrazoic acid, and a variety of medicines ${ }^{[6,17]}$ and acts as a resource for the production of nitrogen gas ${ }^{[18]}$. This compound is also used for introducing nitrogen functionalities into organic compounds, and is often added as an antiseptic and fungicide to the buffer solutions used in biochemistry and clinical examinations ${ }^{[18]}$. Sodium azide is known as a toxic material ${ }^{[6,19-21]}$, and must be handled with caution. Developments in applications of sodium azide which is a toxic material, urged analytical chemists to establish practical methods of identifying and quantifying a trace amount of azide ion in the actual samples with utmost precision. The analytical methods reported so far in such cases were volumetric $^{\left[{ }^{[6]},\right.}$, spectrophotometric ${ }^{[7]}$, high-performance liquid chromatographic (HPLC) ${ }^{[29]}$, ion chromatographic (IC) ${ }^{[10,11]}$, capillary electrophoretic ${ }^{[2]}$, electron paramagnetic resonance ${ }^{[13]}$, selective sensor ${ }^{[14]}$ and stripping voltammetric ${ }^{[15]}$ methods. The volumetric and spectrophotometric methods are unreliable from qualitative and quantitative points of view, especially in a low concentration of azide ion. The HPLC and IC methods are applicable to quantification of a trace amount of the ion with relatively high precision. On the other hand, more reliable analytical methods have been reported in which anions, such as cyanide, thiocyanide or sulfide in biological samples, are transformed by a reaction with pentafluorobenzyl bromide $(\mathrm{PFBBr})$ into the corresponding pentafluorobenzyl derivatives. The derivatives are then identified and quantified with gas chromatography (GC) and gas chromatography-mass spectrometry (GC-MS) ${ }^{[22]}$. A convenient method for determination of sodium azide in beverages using ion chromatography is described in the literature ${ }^{[23]}$. This method combines the specificity for azide with a simple sample preparation using a bubble and trap apparatus that removes any

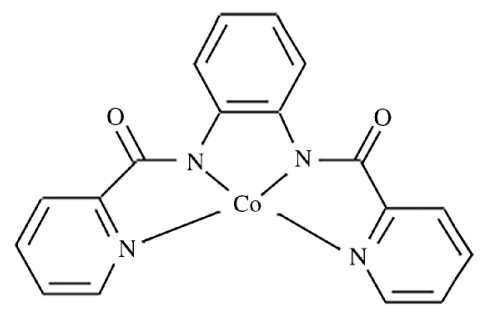

Scheme 1 Structure of $\operatorname{Co}(\mathbf{b p b})$

Received: November 3, 2008; Revised: January 12, 2009; Published on Web: March 3, 2009.

${ }^{*}$ Corresponding author. Email: alizaden@modares.ac.ir; Fax: +98-21-82883455.

The project was supported by the Tarbiat Modares University Research Council.

C Editorial office of Acta Physico-Chimica Sinica 
interferences. Sodium azide in the sample is acidified, and the azide is converted to the volatile hydrazoic acid, which is trapped in $2.5 \mathrm{mmol} \cdot \mathrm{L}^{-1}$ sodium hydroxide solution. The calibration curve is linear for 0.5 to $20 \mu \mathrm{g} \cdot \mathrm{mL}^{-1}$ sodium azide and the detection limit is $0.05 \mu \mathrm{g} \cdot \mathrm{mL}^{-1}[23]$.

Here we report the details of kinetics and thermodynamics investigation on the complexation reaction of $\mathrm{Co}(\mathrm{bpb})$ with $\mathrm{N}_{3}^{-}$ anion to give the trans-addition product $\mathrm{Co}(\mathrm{bpb})-\mathrm{N}_{3}^{-}$in binary $\mathrm{MeOH}$-water solutions. We also present a spectrophotometric determination of $\mathrm{N}_{3}^{-}$anion with $\mathrm{Co}(\mathrm{bpb})$ in water samples.

\section{Experimental}

$\mathrm{Co}(\mathrm{bpb})$ was synthesized and purified according to the literature $^{[1]}$. Other chemicals were of analytical grade and were used without further purification. Absorption spectra were obtained using a Sinco (model UVS-2100) UV-visible spectrophotometer. Measurements were performed in $10 \mathrm{~mm}$ quartz cells, and temperature was controlled at $\pm 0.1{ }^{\circ} \mathrm{C}$, by using a thermostatic cell holder and thermostatic bath. The Datafit version 8.1 software was used for the fitting of the data.

\section{Results and discussion}

The reaction kinetics and thermodynamics of $\mathrm{N}_{3}^{-}$with $\mathrm{Co}(\mathrm{bpb})$ in different binary $\mathrm{MeOH}$-water mixtures $(1.6 \%, 31.0 \%, 43.6 \%$, $63.5 \%$, and $100.0 \%, w$ (mass fraction of $\mathrm{MeOH}$ to water), and at different temperatures (283, 288, 293, 298, and $303 \mathrm{~K}$ ) were investigated using absorption spectra (Fig.1) of the solutions in the wavelength range of 250-370 nm. Fig.1 shows absorption spectra of Co(bpb) (the broad band about $270 \mathrm{~nm}$ ) and its complex with $\mathrm{N}_{3}^{-}$(the broad band about $320 \mathrm{~nm}$ ) in methanol at $298 \mathrm{~K}$. Addition of small amounts of $\mathrm{N}_{3}^{-}$to the $\mathrm{Co}(\mathrm{bpb})$ solution increases absorbance of solution at the wavelength region of about 320 $\mathrm{nm}$, which is related to the complex of $\mathrm{Co}(\mathrm{bpb})$ with $\mathrm{N}_{3}^{-}$. Stoichiometric of complexation was determined by mole-ratio plot titration method and validated with simulation. Kinetics and thermodynamics parameters were calculated in different $\mathrm{MeOH}$ water mixtures using spectral data at different temperatures and fitting them using the law of mass action (reaction (1)) and rate

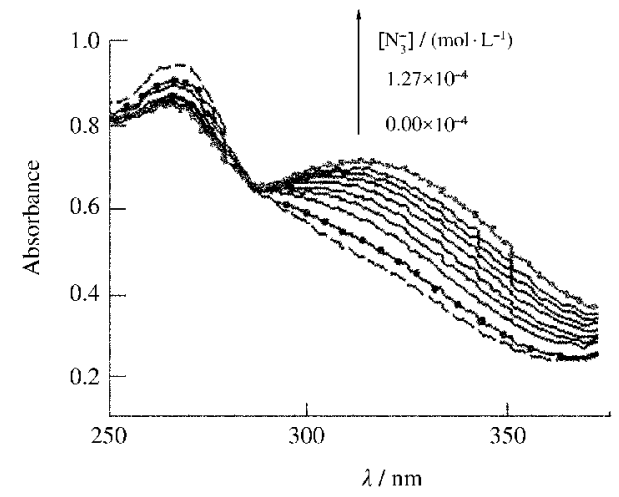

Fig.1 UV-Vis spectra of $\mathrm{Co}(\mathrm{bpb})\left(3.83 \times 10^{-5} \mathrm{~mol} \cdot \mathrm{L}^{-1}\right)$ in the presence of different concentrations of $\mathrm{N}_{3}^{-}$in $\mathrm{MeOH}$ solution at the wavelength range of $250-370 \mathrm{~nm}$ at $298 \mathrm{~K}$ equation (Eq.(2)). Combining the law of mass action and rate equations resulted in Eq.(3), which relates absorbance $(A)$ of the solutions to the initial concentration of the reagents, molar absorbency coefficient of the reagents and products, equilibrium constant of the reaction, forward rate constant and the reaction time. In Eqs.(2-4), [L] and [N] are the initial concentration of the $\mathrm{Co}(\mathrm{bpb})$ and azide, respectively. $k_{\mathrm{f}}$ and $k_{\mathrm{b}}$ are the rate constants of forward and backward reactions and $K_{\mathrm{eq}}$ is the equilibrium constant of the reaction. The $\varepsilon_{\mathrm{p}}$ and $\varepsilon_{1}$ are the molar absorbency coefficients of the product and $\operatorname{Co}(\mathrm{bpb})$, respectively, $t$ is the reaction time, and $Y$ is defined in Eq.(4).

$$
\begin{aligned}
& \mathrm{N}_{3}^{-}+\mathrm{Co}(\mathrm{bpb}) \leftrightarrow\left[\mathrm{Co}(\mathrm{bpb}) \mathrm{N}_{3}^{-}\right] \\
& \text {Rate }=k_{\mathrm{f}}\left[\mathrm{N}_{3}^{-}\right][\mathrm{Co}(\mathrm{bpb})]-k_{\mathrm{b}}\left[\mathrm{Co}(\mathrm{bpb}) \mathrm{N}_{3}^{-}\right] \\
& A=\frac{[\mathrm{L}]\left(\varepsilon_{\mathrm{p}} 2 k_{\mathrm{f}} K_{\mathrm{eq}}[\mathrm{L}]^{-Y Y}+\left(k_{\mathrm{f}}-Y K_{\mathrm{eq}}\right) \varepsilon_{1}^{-t Y}-\varepsilon_{\mathrm{l}}\left(k_{\mathrm{f}}+Y K_{\mathrm{eq}}\right)-2 \varepsilon_{\mathrm{p}} k_{\mathrm{f}} K_{\mathrm{eq}}[\mathrm{L}]\right)}{\left(2 k_{\mathrm{f}} K_{\mathrm{eq}}[\mathrm{L}]-2 k_{\mathrm{f}} K_{\mathrm{eq}}[\mathrm{L}]+k_{\mathrm{f}}-Y K_{\mathrm{eq}}\right)^{-t Y}-Y K_{\mathrm{eq}}-k_{\mathrm{f}}} \\
& Y=\sqrt{\frac{k_{\mathrm{f}}^{2}\left([\mathrm{~N}]^{2} K_{\mathrm{eq}}^{2}-2[\mathrm{~N}][\mathrm{L}] K_{\mathrm{eq}}^{2}+2[\mathrm{~N}] K_{\mathrm{eq}}+[\mathrm{L}]^{2} K_{\mathrm{eq}}^{2}+2[\mathrm{~L}] K_{\mathrm{eq}}+1\right.}{K_{\mathrm{eq}}^{2}}}
\end{aligned}
$$

The absorbance-time curves for solutions containing similar amounts of $\mathrm{Co}(\mathrm{bpb})$ and $\mathrm{N}_{3}^{-}$were recorded at different temperatures. In order to obtain activation parameters, curve fitting was carried out and corresponding rate constant of forward reaction $\left(k_{\mathrm{f}}\right)$ and equilibrium constant of the complexation $\left(K_{\text {eq }}\right)$ at different temperatures were obtained (Eq.(3)). Two samples of the resulting absorbance-time curves and their computer fittings are shown in Fig.2.

The activation parameters $\left(\Delta S^{\#}, \Delta H^{\#}\right.$, and $\left.\Delta G^{\#}\right)$ can be calculated by using Eyring equation (Eq.(5)).

$$
\ln \left(\frac{k_{\mathrm{f}}}{T}\right)=\ln \left(\frac{k_{\mathrm{B}}}{h}\right)+\frac{\Delta S^{\#}}{R}-\frac{\Delta H^{\#}}{R T}
$$

In this equation, $k_{\mathrm{B}}$ is Boltzmann's constant, $T$ is the absolute temperature, $h$ is Plank's constant, $R$ is the gas constant, $\Delta H^{\#}$ and $\Delta S^{\#}$ are the enthalpy and entropy of activation, respectively. The enthalpy and entropy of activation are obtained from the slope and intercept of the Eyring plot (Eq.(5)).

Values of activation energy $\left(E_{\mathrm{a}}\right)$ and the pre-exponential factor $A\left(\mathrm{~L} \cdot \mathrm{mol}^{-1} \cdot \mathrm{s}^{-1}\right)$ were deriving from linear least squares regression plot of $\ln k_{\mathrm{f}} v s 1 / T$ (Arrhenius plots).

The effect of the $\mathrm{MeOH}$ composition on the kinetics and thermodynamics of the complexation reaction was examined at

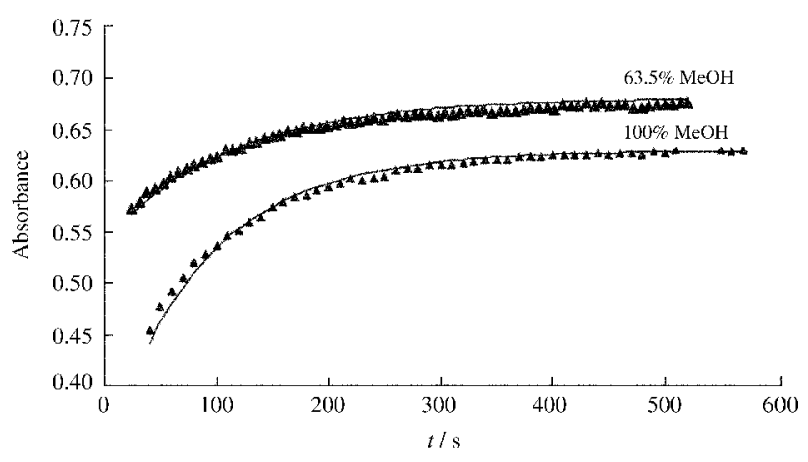

Fig.2 Experimental data recorded at $320 \mathrm{~nm}(\Delta)$ and computer fitted (-) absorbance-time curves for solutions containing $3.97 \times 10^{-5} \mathrm{~mol} \cdot \mathrm{L}^{-1} \mathrm{Co}(\mathrm{bpb})$ and $1.52 \times 10^{-4} \mathrm{~mol} \cdot \mathrm{L}^{-1}$ $\mathrm{N}_{3}^{-}$in $63.5 \%$ and $100 \%(w) \mathrm{MeOH}$ aqueous solutions at $298 \mathrm{~K}$ 
Table 1 Thermodynamic and kinetic parameters of formation of $\operatorname{Co}(\mathbf{b p b})-\mathbf{N}_{3}^{-}$complex

\begin{tabular}{|c|c|c|c|c|c|c|c|c|c|c|}
\hline$w_{\mathrm{MeOH}}(\%)$ & $T / \mathrm{K}$ & $\frac{k_{\mathrm{f}}}{\left(\mathrm{L} \cdot \mathrm{mol}^{-1} \cdot \mathrm{s}^{-1}\right)}$ & $\frac{K_{\mathrm{eq}}}{\left(\mathrm{L} \cdot \mathrm{mol}^{-1}\right)}$ & $\frac{\Delta E^{\#}}{\left(\mathrm{~kJ} \cdot \mathrm{mol}^{-1}\right)}$ & $\frac{\Delta H_{\mathrm{f}}^{\#}}{\left(\mathrm{~kJ} \cdot \mathrm{mol}^{-1}\right)}$ & $\frac{\Delta S_{\mathrm{f}}^{\#}}{\left(\mathrm{~J} \cdot \mathrm{mol}^{-1} \cdot \mathrm{K}^{-1}\right)}$ & $\frac{\Delta G_{\mathrm{f}(298 \mathrm{~K})}^{\#}}{\left(\mathrm{~kJ} \cdot \mathrm{mol}^{-1}\right)}$ & $\frac{\Delta H}{\left(\mathrm{~kJ} \cdot \mathrm{mol}^{-1}\right)}$ & $\frac{\Delta S}{\left(\mathrm{~J} \cdot \mathrm{mol}^{-1} \cdot \mathrm{K}^{-1}\right)}$ & $\frac{\Delta G_{298 \mathrm{~K}}}{\left(\mathrm{~kJ} \cdot \mathrm{mol}^{-1}\right)}$ \\
\hline \multirow[t]{4}{*}{1.6} & 283 & $4.20 \pm 0.05$ & $6800 \pm 700$ & 64.1 & 61.5 & -14.9 & 66.0 & -10.4 & 35.7 & -21.0 \\
\hline & 290 & $9.40 \pm 0.07$ & $4600 \pm 70$ & & & & & & & \\
\hline & 298 & $18.00 \pm 0.12$ & $4650 \pm 30$ & & & & & & & \\
\hline & 303 & $31.70 \pm 0.36$ & $4850 \pm 30$ & & & & & & & \\
\hline \multirow[t]{5}{*}{31} & 283 & $7.50 \pm 0.07$ & $5821 \pm 348$ & 46.6 & 46.2 & -72.2 & 65.6 & -0.22 & 71.7 & -21.6 \\
\hline & 288 & $10.10 \pm 0.07$ & $5874 \pm 165$ & & & & & & & \\
\hline & 293 & $3.80 \pm 0.09$ & $6506 \pm 124$ & & & & & & & \\
\hline & 298 & $20.10 \pm 0.11$ & $6953 \pm 79$ & & & & & & & \\
\hline & 303 & $27.50 \pm 0.16$ & $5287 \pm 31$ & & & & & & & \\
\hline \multirow[t]{5}{*}{43.6} & 283 & $7.50 \pm 0.07$ & $6578 \pm 402$ & 44.5 & 42.0 & -79.3 & 65.7 & -1.1 & 68.3 & -21.5 \\
\hline & 288 & $10.80 \pm 0.09$ & $4892 \pm 115$ & & & & & & & \\
\hline & 293 & $14.30 \pm 0.08$ & $6294 \pm 100$ & & & & & & & \\
\hline & 298 & $20.30 \pm 0.13$ & $6011 \pm 67$ & & & & & & & \\
\hline & 303 & $25.90 \pm 0.13$ & $5715 \pm 35$ & & & & & & & \\
\hline \multirow[t]{5}{*}{63.5} & 283 & $7.50 \pm 0.07$ & $8401 \pm 619$ & 43.7 & 41.2 & -82.3 & 65.8 & -4.6 & 57.7 & -21.8 \\
\hline & 288 & $10.90 \pm 0.08$ & $6461 \pm 193$ & & & & & & & \\
\hline & 293 & $14.60 \pm 0.12$ & $6150 \pm 133$ & & & & & & & \\
\hline & 298 & $17.50 \pm 0.10$ & $6170 \pm 75$ & & & & & & & \\
\hline & 303 & $27.30 \pm 0.18$ & $6737 \pm 70$ & & & & & & & \\
\hline \multirow[t]{5}{*}{100} & 283 & $28.30 \pm 0.17$ & $52971 \pm 2479$ & 50.0 & 47.4 & -49.7 & 62.3 & -24.0 & 5.8 & -25.7 \\
\hline & 288 & $39.50 \pm 0.24$ & $42556 \pm 1294$ & & & & & & & \\
\hline & 293 & $59.20 \pm 0.40$ & $35124 \pm 590$ & & & & & & & \\
\hline & 298 & $80.00 \pm 0.73$ & $28719 \pm 404$ & & & & & & & \\
\hline & 303 & $114.60 \pm 0.89$ & $27958 \pm 273$ & & & & & & & \\
\hline
\end{tabular}

different $\mathrm{MeOH}$ concentrations $(0,1.6 \%, 31.0 \%, 43.6 \%, 63.5 \%$, and $100 \%(w))$. Table 1 shows the results obtained from fitting the spectral data to Eq.(3), for calculating thermodynamic (equilibrium constant) and kinetic parameters (rate constant) of reaction (1). The activation parameters $\left(\Delta S^{\#}, \Delta H^{\#}\right.$, and $\left.\Delta G^{\#}\right)$ are summarized in Table 1. Fig.3(a) shows the effect of $\mathrm{MeOH}$ content in the solution on the forward activation parameters $\left(\Delta H_{\mathrm{f}}^{*}, \Delta S_{\mathrm{f}}^{\#}\right)$ and $\Delta G$. As illustrated in Fig.3(a) the forward enthalpy and entropy of activation remain constant within $\mathrm{MeOH}$ concentration ranges of approximately $40 \%-70 \%$. Variation of the activation enthalpy and entropy at $w(\mathrm{MeOH})<40 \%$ and $w(\mathrm{MeOH})>70 \%$ could be related to solvent-solvent interaction, which results in a decrease of the enthalpy and entropy for $w(\mathrm{MeOH})<40 \%$ and an increase for $w(\mathrm{MeOH})>70 \%$ of activation. A fairly good correlation can be found between $\Delta H_{\mathrm{f}}^{\#}$ and $\Delta S_{\mathrm{f}}^{\#}$ of the complexation

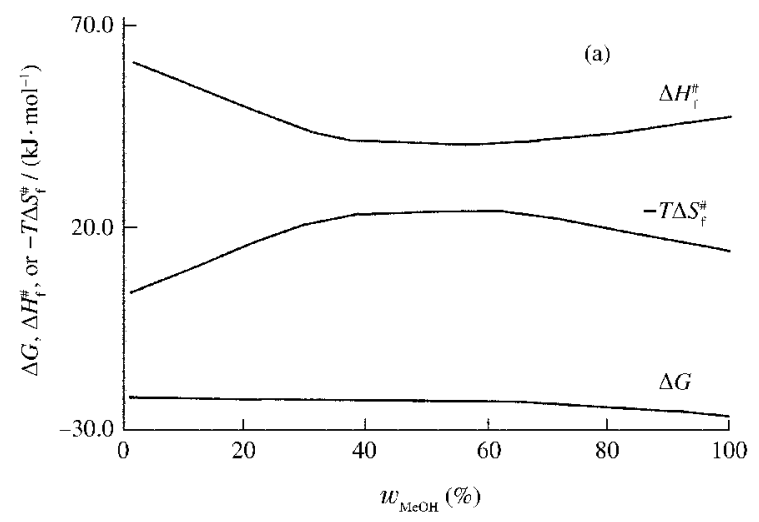

reaction in different $\mathrm{MeOH}$-water compositions (Table 1) and excess molar enthalpy of MeOH-water mixtures is shown in Fig.3 (b) ${ }^{[24]}$. The minimum value of excess molar enthalpy of $\mathrm{MeOH}-$ water mixture is observed at molar fraction of $0.2-0.6$ corresponding to $31 \%-63 \%(w) \mathrm{MeOH}$, where in this solvent composition, the activation enthalpy of complexation reaction is minimized.

In order to find isokinetic temperature for the reaction, compensation plot was plotted according to Eq.(6) $\left(\ln A_{\mathrm{i}}\right.$ versus $E_{\text {ai }}$ (the experimentally determined activation energy)) and shown in Fig.4 (a). The linear relationship is consistent with compensation behavior where the $T_{\text {iso }}$ can be extracted from the slope according to Eq. $(6)^{[25]}$ and equals $302 \mathrm{~K} \quad\left(29{ }^{\circ} \mathrm{C}\right)$ at which the formation rate constant of $\mathrm{Co}(\mathrm{bpb})-\mathrm{N}_{3}^{-}\left(k_{\mathrm{iso}}=25.2 \mathrm{~s}^{-1}\right)$ is independent of the solvent composition.

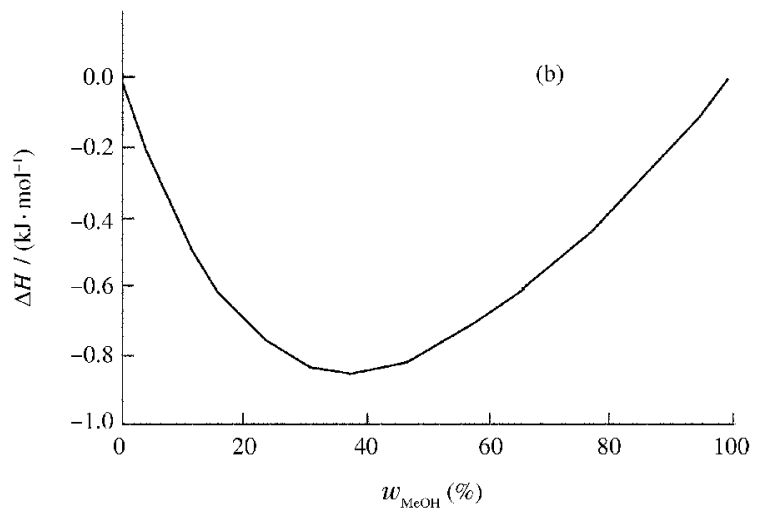

Fig.3 Effect of MeOH content in solution on the kinetics and thermodynamics of complexation reaction between Co(bpb) and $\mathbf{N}_{3}^{-}$ion (a); excess molar enthalpy of MeOH-water mixtures ${ }^{[24]}(\mathrm{b})$ 

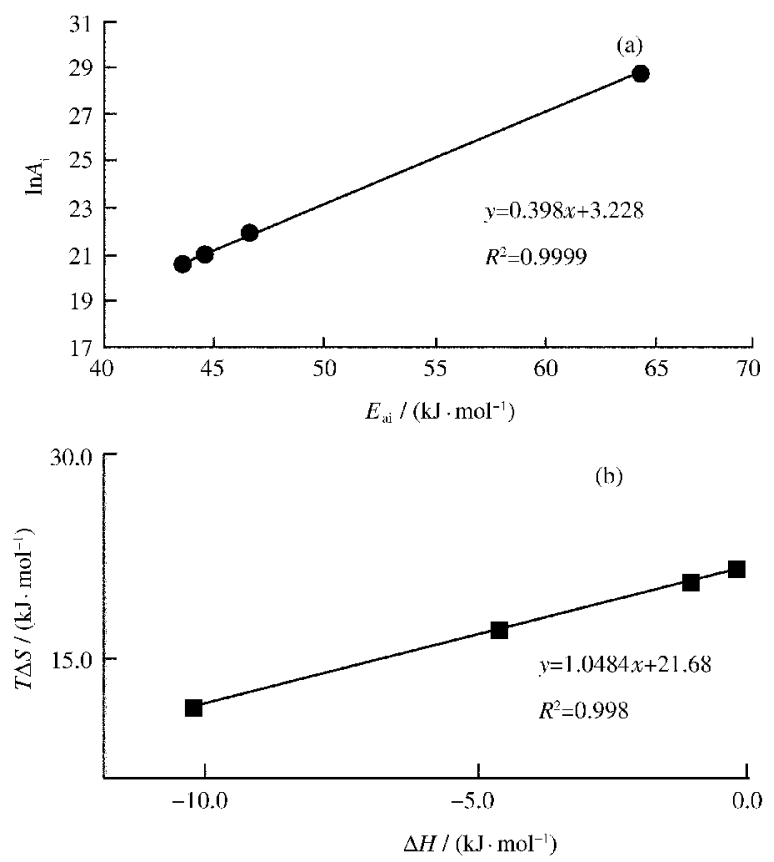

Fig.4 The "compensation plot" for the $\operatorname{Co}(\mathbf{b p b})-\mathrm{N}_{3}^{-}$system in different $\mathrm{MeOH}(0-63.5 \%)$-water compositions (a); linear correlation between $T \Delta S$ and $\Delta H$ for $\operatorname{Co}(\mathrm{bpb})-\mathrm{N}_{3}^{-}$system (b)

$$
\ln A_{\mathrm{i}}=\ln k_{\text {iso }}+\frac{E_{a \mathrm{i}}}{R T_{\text {iso }}}
$$

Compensation effect between enthalpy and entropy of the complexation of $\mathrm{Co}(\mathrm{bpb})-\mathrm{N}_{3}^{-}$in different compositions of $\mathrm{MeOH}$ water as solvent is shown in Fig.4(b). This is in agreement with constant free energy of the complexation reaction in different compositions of $\mathrm{MeOH}$ (Table 1).

The reaction of $\mathrm{N}_{3}^{-}$with $\mathrm{Co}(\mathrm{bpb})$ was used for the determination of $\mathrm{N}_{3}^{-}$in water samples. A calibration curve was plotted using the absorbance at $320 \mathrm{~nm}$ for the concentration range of 0.00 to $5.00 \times 10^{-4} \mathrm{~mol} \cdot \mathrm{L}^{-1}$ solution of $\mathrm{N}_{3}^{-}$containing $3.10 \times 10^{-4} \mathrm{~mol} \cdot \mathrm{L}^{-1}$ of $\mathrm{Co}(\mathrm{bpb}$ ) in water, $\mathrm{pH}=7.5$ (Fig.5). Based on the calibration curve, some figures of merit of the method for the determination of $\mathrm{N}_{3}^{-}$were calculated and are summarized in Table 2. Studies on the effect of $\mathrm{pH}$ on the absorption spectra of $\mathrm{Co}(\mathrm{bpb})$ and $\mathrm{Co}(\mathrm{bpb})-$ $\mathrm{N}_{3}^{-}$complex showed that both spectra are independent of the solution $\mathrm{pH}$ in the $\mathrm{pH}$ range of 6.5-8.7. It was found that for the optimum $\mathrm{pH}$ range, the absorbance was linear for $\mathrm{N}_{3}^{-}$ions, over the concentration range $(0.85-5.00) \times 10^{-4} \mathrm{~mol} \cdot \mathrm{L}^{-1}$ with a calibrat-

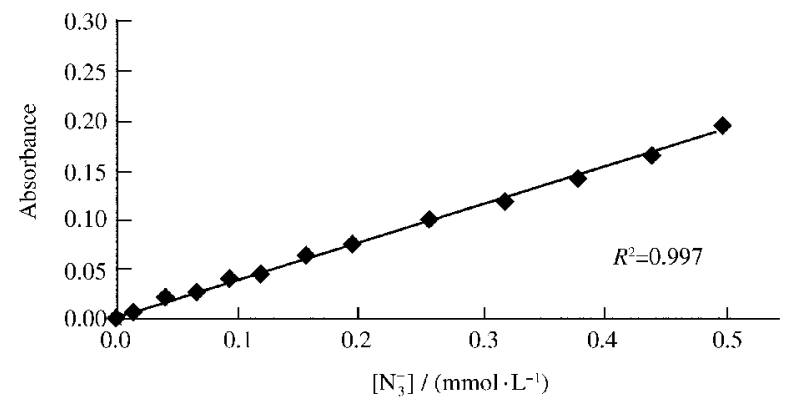

Fig.5 Calibration curve for determination of $\mathrm{N}_{3}^{-}$with using Co(bpb) at $320 \mathrm{~nm}$
Table 2 Figures of merit and tolerance ratio for foreign ions in the determination of $3.3 \times 10^{-4} \mathrm{~mol} \cdot \mathrm{L}^{-1} \mathrm{~N}_{3}^{-}$by $\mathrm{Co}(\mathrm{bpb})$

\begin{tabular}{lcc}
\hline \multicolumn{1}{c}{ Figures of merit } & Tolerance ratio & Foreign ions \\
\hline $\mathrm{LOD}\left(3 S_{\downarrow} / \mathrm{m}\right): 2.50 \times 10^{-5} \mathrm{~mol} \cdot \mathrm{L}^{-1}\left(1.0 \mu \mathrm{g} \cdot \mathrm{mL}^{-1}\right)$ & $<100$ & $\mathrm{~F}^{-}, \mathrm{Cl}^{-}, \mathrm{Na}^{+}, \mathrm{K}^{+}$ \\
$\mathrm{LOQ}\left(10 S_{\downarrow} / \mathrm{m}\right): 8.50 \times 10^{-5} \mathrm{~mol} \cdot \mathrm{L}^{-1}\left(3.6 \mu \mathrm{g} \cdot \mathrm{mL}^{-1}\right)$ & $<20$ & $\mathrm{Br}^{-}, \mathrm{I}^{-}, \mathrm{NO}_{3}^{-}$ \\
dynamic linear range: $(0.85-5.0) \times 10^{-4} \mathrm{~mol} \cdot \mathrm{L}^{-1}$ & $<10$ & $\mathrm{SO}_{4}^{2-}, \mathrm{HCO}_{3}^{-}$ \\
$\left(3.6-21 \mu \mathrm{g} \cdot \mathrm{mL}^{-1}\right)$ & $<4$ & $\mathrm{SO}_{3}^{2-}, \mathrm{SCN}^{-}, \mathrm{CN}^{-}$ \\
calibration sensitivity $(\mathrm{m}): 389 \mathrm{~mol}{ }^{-1} \cdot \mathrm{L}$ & $<$ in & \\
\hline${ }^{a}$ Tolerance ratio is defined as the ratio in which the absorbance of solution does \\
not vary more than $5 \%$. LOD: limit of detection, LOQ: limit of quantitation, $\mathrm{S}_{\mathrm{b}}$ : \\
standard deviation of the blank
\end{tabular}

ion sensitivity $389 \mathrm{~mol}^{-1} \cdot \mathrm{L}$ (Table 2 ). The limit of detection (LOD) was $2.50 \times 10^{-5} \mathrm{~mol} \cdot \mathrm{L}^{-1}$ and reputability was evaluated by repeated calibration curve for $\mathrm{N}_{3}^{-}$in solutions.

The interference effect of some ions and the effect of $\mathrm{pH}$ on the determination of $\mathrm{N}_{3}^{-}$were investigated. Results of interference study of some ions are summarized in Table 2. It is evident from the data in Table 2 that the absorbance variation based on the $\mathrm{Co}(\mathrm{bpb})$ complex has relatively good selectivity toward $\mathrm{N}_{3}^{-}$ relative to anions such as $\mathrm{F}^{-}, \mathrm{Cl}^{-}, \mathrm{Br}^{-}, \mathrm{I}^{-}, \mathrm{NO}_{3}^{-}, \mathrm{SO}_{4}^{2-}, \mathrm{HCO}_{3}^{-}$and several common cations. The reason for the selectivity of $\mathrm{Co}(\mathrm{bpb})$ for the azide ion is thought to be due to the possible interaction of the $\mathrm{Co}(\mathrm{bpb})$ with $\pi$-acceptor anions $\left(\mathrm{N}_{3}^{-}\right)$. However, other $\pi$ acceptor anions, such as $\mathrm{SO}_{3}^{2-}, \mathrm{SCN}^{-}$and $\mathrm{CN}^{-}$, show the interference effect.

Because of the good selectivity and the low detection limit of the proposed method for $\mathrm{N}_{3}^{-}$, it was applied for the determination of the azide ion concentration in various aqueous samples (mineral water and ground water samples). A mineral water and a ground water sample were used as real samples. The effect of sample solution matrix on the spectrophotometric determination of azide with the proposed method was investigated in detail. For this purpose, $25.0 \mathrm{~g}$ of water sample was acidified by $\mathrm{HCl}$ (2 $\mathrm{mol} \cdot \mathrm{L}^{-1}$ ) to the $\mathrm{pH}$ of 1.5 . Azide is readily protonated in the acidic aqueous solution to yield volatile hydrazoic acid $\left(\mathrm{HN}_{3}\right)$ that can be evaporated at boiling point ${ }^{[23]}$ and examined as background solution for absorption measurements. The $\mathrm{pH}$ of the samples was then adjusted to the original $\mathrm{pH}$ (8.6 for ground water and

Table 3 Results of the determination of azide ion in real water samples by using proposed spectrophotometric method

\begin{tabular}{|c|c|c|c|c|}
\hline \multirow{2}{*}{ Sample } & \multicolumn{2}{|c|}{ Concentration $\left(\mathrm{mol} \cdot \mathrm{L}^{-1}\right)$} & \multirow{2}{*}{$\operatorname{RSD}(\%)$} & \multirow{2}{*}{ Recovery $(\%)$} \\
\hline & add & found & & \\
\hline \multirow[t]{6}{*}{ mineral water } & 0 & below LOD & - & - \\
\hline & $5.00 \times 10^{-5}$ & $4.48 \times 10^{-5}$ & 2.4 & 88.1 \\
\hline & $9.98 \times 10^{-5}$ & $1.00 \times 10^{-4}$ & 0.3 & 100.2 \\
\hline & $1.50 \times 10^{-4}$ & $1.52 \times 10^{-4}$ & 0.6 & 101.6 \\
\hline & $2.49 \times 10^{-4}$ & $2.60 \times 10^{-4}$ & 0.5 & 104.5 \\
\hline & $3.48 \times 10^{-4}$ & $3.70 \times 10^{-4}$ & 0.4 & 106.5 \\
\hline \multirow[t]{6}{*}{ ground water } & 0 & below LOD & - & - \\
\hline & $9.98 \times 10^{-5}$ & $7.75 \times 10^{-5}$ & 0.5 & 80.7 \\
\hline & $1.50 \times 10^{-4}$ & $1.30 \times 10^{-4}$ & 1.1 & 86.9 \\
\hline & $2.49 \times 10^{-4}$ & $2.40 \times 10^{-4}$ & 1.0 & 96.5 \\
\hline & $3.48 \times 10^{-4}$ & $3.55 \times 10^{-4}$ & 0.6 & 102.1 \\
\hline & $4.46 \times 10^{-4}$ & $4.64 \times 10^{-4}$ & 1.2 & 104.0 \\
\hline
\end{tabular}


7.8 for mineral water) by addition of minute volumes of $\mathrm{NaOH}$. The mass of the samples was adjusted to $25.0 \mathrm{~g}$ by the addition of doubly distilled water to the samples. For each sample, precision and recovery were measured by adding different amount of azide into the water samples. Recovery for all samples was greater than $80 \%$. Precision varied from $0.3 \%$ to $2.4 \%$ for all the samples. The results are shown in Table 3 . It is evident that the results are in good agreement with actual values and the method is capable of analyzing azide in water samples.

\section{Conclusions}

The kinetics of complexation of the $\mathrm{N}_{3}^{-}$ion with $\mathrm{Co}(\mathrm{bpb})$ is dependent on the composition of solvent. On the basis of the results discussed in this paper, the $\mathrm{Co}(\mathrm{bpb})$ complex can be regarded as a probe for $\mathrm{N}_{3}^{-}$ion determination. The proposed method has been shown to have good figure of merits, dynamic linear range $\left.(0.85-5.00) \times 10^{-4} \mathrm{~mol} \cdot \mathrm{L}^{-1}\right)$, and low detection limit $\left(2.50 \times 10^{-5}\right.$ $\mathrm{mol} \cdot \mathrm{L}^{-1}$ ) and good selectivity make it potentially useful for monitoring low concentration levels of $\mathrm{N}_{3}^{-}$in different aqueous samples. From the point of view in analyzing some poisonous anions in biological and environmental media, this complex could have importance in analytical chemistry.

\section{References}

1 Amirnasr, M.; Schenk, K. J.; Meghdadi, S. Inorg. Chim. Acta, 2002, 19: 338

2 Ray, M.; Mukhrjee, R. N. Polyhedron, 1992, 11: 2929

3 Coichev, N.; Neves, E. A. Polyhedron, 1989, 8: 641

4 Yoo, H. S.; Kim, J. I.; Yang, N.; Koh, E. K.; Park, J. G.; Hong, C. S. Inorg. Chem., 2007, 46: 9054

5 Meghdadi, S.; Mereiter, K.; Amirnasr, M.; Fadaee, F.; Amiri, A. J. Coord. Chem., in press

6 Kozlicka-Gajdzinska, H.; Brzyski, J. Arch. Toxicol., 1966, 22: 160
7 Klug, E.; Schneider, V. Z. Rechtsmed, 1987, 98: 129

8 Howard, J. D.; Skogerboe, K. J.; Case, G. A.; Raisys, V. A.; Lacsina, E. Q. J. Forensic Sci., 1990, 35: 193

9 Lambert, W. E.; Piette, M.; van Peteghem, C.; de Leenheer, A. P. J. Anal. Toxicol., 1995, 19: 261

10 Kruszyna, R.; Smith, R. P.; Kruszyna, H. J. Forensic Sci., 1998, 43: 200

11 Perati, P.; Rohrer, J.; Thomas, D. LC-GC North America, 2006, 17: 24

12 Pirogov, A. V.; Yurev, A. V.; Shpigun, O. A. J. Anal. Chem., 2003, 58: 781

13 Minakata, K.; Suzuki, O. Anal. Chim. Acta, 2005, 554: 202

14 Singh, A. K.; Singh, U. P.; Aggarwal, V.; Mehtab, S. Anal. Bioanal. Chem., 2008, 391: 2299

15 Kovaleva, S. V.; Gladyshev, V. P.; Dubrovka, A. M. J. Anal. Chem., 2006, 61: 258

16 Hagenbuch, J. P. Chimia, 2003, 57: 773

17 Chang, S. J.; Lamm, S. H. Int. J. Toxicol., 2003, 22: 175

18 Kikuchi, M.; Sato, M.; Ito, T.; Honda, M. J. Chromatogr. B, 2001, 752: 149

19 Roberts, R. J.; Simmons, A.; Barrett, D. A. Am. J. Clin. Pathol., 1974, 61: 879

20 Richardson, S. G.; Giles, C.; Swan, C. H. J. J. Clin. Pathol., 1975, 28: 350

21 Emmett, E. A.; Ricking, J. A. Ann. Intern. Med., 1975, 83: 224

22 Kage, S.; Nagata, T.; Kimura, K.; Kudo, K. J. Forensic Sci., 1988, 33: 217

23 Oshima, H.; Ueno, E.; Saito, I.; Matsumoto, H. J. AOAC, 2000, 83: 1410

24 Gonzàlez-Salgado, D.; Nezbeda, I. Fluid Phase Equilibr., 2006, 240: 161

25 Bond, G. C.; Keane, M. A.; Kral, H.; Lercher, J. A. Catal. Rev. Sci. Eng., 2000, 42: 323 